\title{
FACTORS AFFECTING LOCAL FARMERS ADOPTION OF EUCALYPTUS WOODLOT IN JAMMA DISTRICT, SOUTH WOLLO ZONE, AMHARA REGIONAL STATE OF ETHIOPIA
}

\author{
Tesfanesh Ababu Kebede \\ Ethiopian Environment and Forest Research institute EEFRI, P.O.BOX 2322, Addis Ababa, \\ Ethiopia.
}

Article DOI: https://doi.org/10.36713/epra6132

\begin{abstract}
Eucalyptus is one of the most widely planted exotic tree species grown in Ethiopia. The spices have been planted as a woodlot by local farmers and became one of the most economically important tree plants. The main objective of the study was to identify factors that determine the local farmers' decision making of eucalyptus woodlot production in Jamma District, Ethiopia. The survey was carried out on 150 local farmers who were selected through systematic random sampling. The collected raw data were analyzed through descriptive statistics and binary logistic regression analysis. The result of the study shows that landholding size, Farmers' education level; the age of the farmers were positive significantly affecting the adoption of eucalyptus woodlot. On the other hand fertility of land, family size and distance from the market was affecting the farmer's adoption of Eucalyptus woodlot production negatively. To protect the forest from deforestation and increase the income of households, it recommends that policymakers should work with stakeholders to create an enabling policy environment to support Eucalyptus production in Ethiopia.
\end{abstract}

KEYWORDS: Adoption, Eucalyptus Tree, Farmers, Plantation, Woodlot, Ethiopia.

\section{INTRODUCTION}

Eucalyptus plantation is mainly started in Ethiopia in 1895 , to satisfy the increasing demand for construction poles and firewood in the capital city of Ethiopia, Addis Ababa (Yetebitu Moges, 2010). Eucalyptus plantations playing an important role as the major source of fuelwood, construction materials, and provide income for both urban and rural dwellers (Zerfu, 2002). In Ethiopia, where there are huge gaps between demand and supply of wood which lead to exploitations of natural resources and caused deforestation in past twenty years. Using fastgrowing species to produce a huge quantity of wood like eucalyptus was extensively increasing nationwide since 1895. Eucalyptus is the most commonly grown tree species in most parts of Ethiopia as a community and household woodlots (Duguma et al, 2009). This tree species grows well even on infertile soils and grows faster compared to most indigenous tree species like Cordia Africana, Juniperus procera, and Hagenia abyssinica. Eucalyptus is a popular tree crop due to its fast growth and easy establishment properties. Local farmers used it to meet their demand for different products and services, and they have gained a strong local knowledge of the various Eucalyptus species management (Gessesse Dessie, 2011). Eucalyptus woodlots have the power of changing farmers' livelihoods to a better lifestyle. Planting eucalyptus is more preferable than other tree species in most parts of the country. It is an important source of industrial input, farm tools, transmission poles, and guarantees for food security at the time of hardship for smallholder farmers in the rural area. Moreover, it creates job opportunities directly and indirectly for others. In the study area, local farmers have been using white eucalyptus (Eucalyptus globules) woodlot as an important cash income source and are going to replace their land from food 


\section{EPRA International Journal of Research and Development (IJRD)}

crops to eucalyptus production. On the other hand, many other local farmers who did not participate in eucalyptus woodlot production were observed. In this area, the study was not carried out to identify the reason why some farmers are not engaged in eucalyptus woodlot production to use as an income source. Therefore, this study was conducted to investigate the factors that determine local farmers' adoption of eucalyptus woodlot production with an attempt to fill the existing knowledge gap.

\section{RESEARCH METHODOLOGY}

\subsection{Description of the study area}

The study was conducted in Jamma district, which is found in the north-eastern part of Amhara

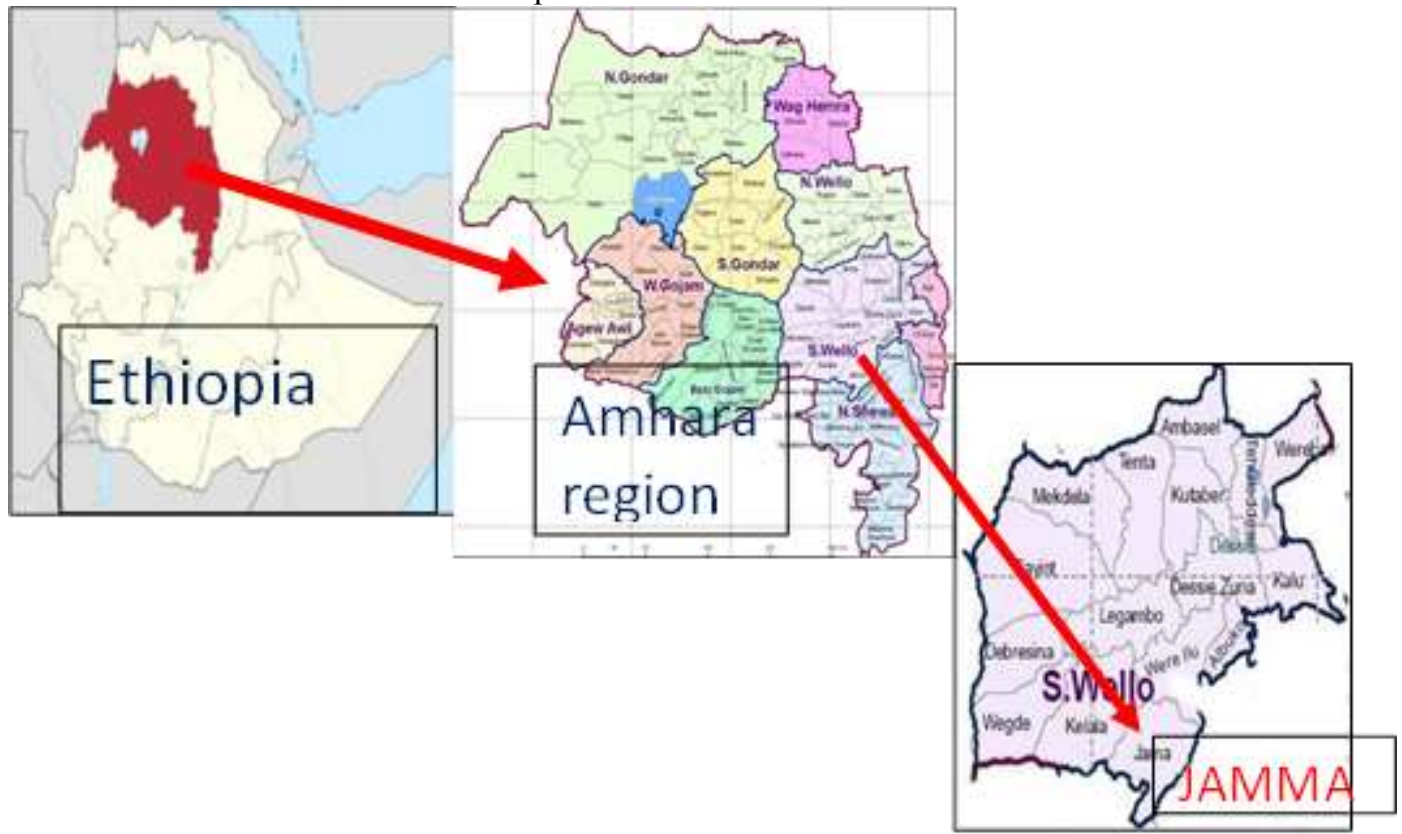

Figure 1: Study Area Location

\subsection{Methods of Data Collection}

The data was collected from jamma district of north-eastern Amhara, Ethiopia, were eucalyptus woodlot has been widely expanded. Prior to the actual survey, author visited jamma district to gather the secondary information relevant to the study. A formal data collection were carried out by using a structured questionnaire aimed for capturing both quantitative and qualitative information's, following the methods of (Endalew, 2016), (2010) and (Matiku, 2012). The questionnaires were administered using a personal interview approach, which is recommended to avoid non-responsive bias (Harrison S., 2002). Therefore, the questionnaires written in English were translated into 'Amharic' of the local language in which the interview will be conducted to control the quality of data and minimize errors.
National Regional State, South Wollo Zone, Ethiopia. The geographical location of the district lies between $10^{\circ} 23^{\prime} 0^{\prime \prime}$ and $10^{\circ} 27^{\prime} 0^{\prime \prime} \mathrm{N}$ latitude and between $39^{\circ} 07^{\prime} 0$ " and $39^{\circ} 24^{\prime} 0$ " E longitude. It has an altitude ranges from 1600 to $2776 \mathrm{~m}$ above sea level. It is bordered by Legahida, Mida, Gera Mider, and Kelala from the north, south, east, and west respectively. On the southeast, it is also bordered by the Qechene River which separates it from North Shewa Zone. Its capital town is called "Degolo", which is about 260 $\mathrm{km}$ away from Addis Ababa and $110 \mathrm{~km}$ far from the zonal city of South Wollo Zone, Dessie.
2.2.1 Sampling Procedure
Sampling allows us to gather information from a smaller, more manageable subset of the population. That information can be used to constitute the greater population. There are altogether 240 households in the target villages. The sample size was calculated at $5 \%$ precision level by using the formula developed by Taro Yamane (Yamane, 1967).

$$
n=\frac{N}{1+N e^{2}}
$$

Where; $\mathrm{n}=$ sample size $\mathrm{N}=$ total population of household $\mathrm{e}=$ precision level

Thus, the result of the sample size calculation 240/ $\left(1+240 *(0.05)^{2}\right)$ was 150 . Then, it was equally allocated to each target of the three villages. Preliminary data on qualitative and quantitative were directly collected from the local farmers in the Jamma District to where the intended of three villages (namely Gomenty, Yejerty, and Micha) 


\section{EPRA International Journal of Research and Development (IJRD)}

where eucalyptus woodlot production widely experienced. One hundred fifty (150) eucalyptus woodlot owner farmers were randomly selected and interviewed using the questionnaire.

\subsection{Methods of Data Analysis}

Binary logistic regression analysis was used to address the main objective of this study. After the completion of data collection, data were coded and entered into Stata version 13 computer programs for analysis. The goal of this study was identifying the factors that determine local farmers' adoption of eucalyptus woodlot production. It was used to analyze the determinants of the local farmers' adoption in Eucalyptus woodlot production and the data were described to explain the relationship between the dependent binary variables and independent variables. In the logistic regression, the dependent variable was a binary response were Eucalyptus woodlot adopter labeled as 1 and 0 otherwise. Independent variables like; age, sex (female and male), educational level, distance from the market, family size, Fertility of land, and landholding size were used for data analysis. The logistic model ensures that the estimated response probabilities were strictly between zero and one. The definition of the variables included in the logistic regression model was stated in (Table 2.1). $\mathrm{P}(\mathrm{y}=1 \mid \mathrm{x})$ $=\mathrm{G}\left(\beta 0+\beta 1 \mathrm{Ag}+{ }_{\beta} 2 \mathrm{Gd}+\beta 3 \mathrm{Fs}+\beta 4 \mathrm{El}+{ }_{\beta} 5 \mathrm{Ds}+\beta 6 \mathrm{Lhs}\right.$ $+\beta 7 \mathrm{FL})$.

Table 1.1 : Description of Logistic Variables and Their Expected Sign

\begin{tabular}{lllll}
\hline Variables Description & Abbr. & Unit & Measurements & $\begin{array}{l}\text { Expected } \\
\text { Sign }\end{array}$ \\
\hline EWLP Adoption & EWLA & EWL adopters 1,0 otherwise & dummy variables & $\begin{array}{l}\text { Dependent } \\
\text { variables }\end{array}$ \\
Age & Ag & Year & Continuous & - \\
Gender & Gd & Male 1, 0 otherwise & Dummy & + \\
Family size & Fs & Numeral & Continuous & + \\
Educational level & El & Numeral & Continuous & + \\
Distance & Ds & Km & Continuous & - \\
Landholding size & Lhs & Ha & Continuous & + \\
Fertility of land & FL & Fertile 1, 0 infertile & Dummy & + \\
\hline
\end{tabular}

Where;

$\beta_{0}-$ Intercept

$\beta_{1} \ldots \beta_{7}-$ the parameter which measures the change

in EWL Adoption concerning Ag ... Lhs, holding other factors fixed

$\mathrm{P}=$ Probability

$\mathrm{G}=$ Logistic functions ( Gujarati, 2007)3. Results and discussion

\subsection{Demographic and Socioeconomic \\ Characteristics of Sampled Farmers}

Descriptive statistics were performed to analyze the socio-economic characteristics of the sampled farmers. The variables used for this section are age, gender, educational status, family size. Therefore, the data output of descriptive statistics of general sampled households' information was presented in table 3.1. The result shows that the majority of the sampled farmers were men $(82.67 \%)$ and $17.33 \%$ are women. This is indicated that male farmers are more adopted eucalyptus production than females in the study area. The educational level of the household was categorized into four groups. Namely, elementary whose educational level is below nine years of education, a secondary school whose educational level is nine up to twelve years of education according to the educational curriculum of Ethiopia. According to survey results, $28.67 \%$ of the respondents were illiterate, $55.33 \%$ were attended elementary school and $16.00 \%$ were attended secondary school (table 3.1). The educational level of households has been one of the main factors in the adoption of EWL. 


\section{EPRA International Journal of Research and Development (IJRD)}

Volume: 6 | Issue: 1 | January 2021

- Peer Reviewed Journal

Table 3.1 General information on the socio-economic characteristic of sampled farmers

\begin{tabular}{|c|c|c|c|c|c|c|}
\hline & & Adop & $N=100)$ & $\begin{array}{l}\text { Non } \\
(\mathrm{N}=\end{array}$ & $\begin{array}{l}\text { adopte } \\
\text { 50) }\end{array}$ & \\
\hline & & Freq. & Perc. & Freq. & perc. & Cumulative Percent \\
\hline & Elementary & 55 & 55 & 28 & 56 & 83 \\
\hline & Illiterate & 30 & 33.33 & 13 & 3.8 & 28.67 \\
\hline Educational Status & Secondary School & 14 & 7.1 & 10 & 5 & 16.00 \\
\hline & Female & 16 & 6.25 & 10 & 5 & 17.33 \\
\hline Gender & Male & $\begin{array}{l}100 \\
53\end{array}$ & $\begin{array}{l}1.00 \\
53\end{array}$ & $\begin{array}{l}24 \\
40\end{array}$ & $\begin{array}{l}48 \\
12\end{array}$ & $\begin{array}{l}82 \\
62.00\end{array}$ \\
\hline Age & $\begin{array}{l}30-50 \\
51-60 \\
>61\end{array}$ & $\begin{array}{l}30 \\
5\end{array}$ & $\begin{array}{l}33 \\
20\end{array}$ & $\begin{array}{c}20 \\
2\end{array}$ & $\begin{array}{c}4 \\
25\end{array}$ & $\begin{array}{l}33.33 \\
4.67\end{array}$ \\
\hline Family Size & $\begin{array}{l}5-8 \\
9-13 \\
1-4\end{array}$ & $\begin{array}{l}40 \\
20 \\
32\end{array}$ & 25 & $\begin{array}{c}17 \\
19 \\
22\end{array}$ & & $\begin{array}{c}38.00 \\
26.00 \\
36.00\end{array}$ \\
\hline
\end{tabular}

The age structure of the households is classified into three groups (30- 50years), (51-61 years), and over 61 years old, about $62.00 \%, 33.33 \%$, and $4.67 \%$ of sampled households were interviewed respectively. These surveys consist of different age categories; participation from people of different ages provides reliability for analysis. More precisely, according to (Ho, et al, 2012) middle-aged(30-50) categories can be considered as more informative and conscious groups in society, who can focus on the country's social and political activities and better assess society's choice. The total family size of the interviewed households was ranged between 1 and 13 members. Among the local farmers households $38 \%$ of them have between 5 and 8 family size. While the smallest was $26.00 \%$ with 9 and 13 family sizes.

\subsection{Factors affecting local farmers' adoption of eucalyptus woodlot production}

The logistic regression model was employed to analyze factors affecting local farmers' adoption of eucalyptus woodlot production. In the model used, "adopter" means that, a local farmer who produces eucalyptus woodlot and otherwise considered as "non-adopter". Accordingly, the results in (Table 3.1) were shows that five variables were affecting the adoption of eucalyptus woodlot by local farmers and found to be statistically significant. Hence, Landholding size, education, and Family size affect positively on the other hand distance from the market and fertility of land affect negatively, whereas the rest dependent variables were found to have not affecting the adoption of eucalyptus woodlot production significantly. The significant dependent variables that affect eucalyptus woodlot production in the study area were discussed as follows:

\subsubsection{Family size}

It was found that the family size of the farmers has positively related to the adoption of eucalyptus woodlot by local farmers and it affected significantly, at less than $10 \%$ significant level. The coefficient of (1.319) for family size indicates that keeping the influence of all other factors fixed, as the family size increases by one, the local farmers' decision to adopt eucalyptus woodlot production will increase by 1.319 in the study area. The result shows that farmers who have large family sizes are not devoted to adopt eucalyptus woodlot production than farmers with small family sizes. This is due to availability of sufficient household labor force in large families to engage in intensive crop production activities (Summers, et al, 2004) and (Nsiah, 2010) However, the study by (Dereje et al, 2012) indicates that the total family size had no significant effect on farmers' decision to plant eucalyptus.

\subsubsection{Landholding size}

The result shows that farmer's land size had affected positively and significantly, the probability of local farmers adopting eucalyptus woodlot was less than $5 \%$ significant level. The coefficient of 0.442 for landholding size indicates that keeping the 


\section{EPRA International Journal of Research and Development (IJRD)}

influence of all other factors fixed, the adoption of eucalyptus woodlot by local farmers will increase by a factor of 0.442 as land size increases by one hectare. Hence, adoptions of eucalyptus woodlot production by local farmers were connected positively and significantly with land holding size. As shows in the result that farmers who have large land sizes are more devoted to adopt eucalyptus woodlot than the farmers who have small land size in the study area (Shifa, et al 2015). Land size is a very important resource to practice in eucalyptus woodlot production, because farmers divide their land for different activities, such as growing different crops, rearing diverse animals, and thereby likely to generate sufficient income, which could help them to produce or/and buy required food and non-potential factor in household tree planting and positively correlated with households' decision to plant and allocates land for eucalyptus woodlot.

\subsubsection{Fertility of farmers' land}

As shows in the result the probability of local farmer's adoption of eucalyptus woodlot production is negatively connected to the fertility of the land and significant at less than $1 \%$ significant level. The coefficient 1.945 for the fertility of land owned by the local farmers implies that local farmers who have unsuitable land for crop production are 1.945 times more likely to adopt eucalyptus woodlot compared to local farmers with fertile land which is suitable for crop production. The result indicates that the local farmers are more committed to plant eucalyptus woodlot when the fertility of their land decline. In the study area, the farmers who have fertile lands are focused on crop production to produce enough amounts of food crops in order to enable of feeding their families. Whereas, the medium fertile or infertile land is not suitable for crop production, hence they were changing their land to eucalyptus woodlot production. (Nsiah, 2010) also pointed out in his report that farmers use their infertile land for plantation purpose while productive lands were reserved for agricultural crop production. Similarly, (Kebede Gizachew, 2017) indicated that the farmlands should be changed to eucalyptus woodlot production to improve the productivity of the land, when the land is not productive since the farmers cannot produce agricultural products.

\subsubsection{Distance from the market}

The result shows that the location of farm land from the market were farmers can sell their products were related positively and significantly with the adoption of eucalyptus woodlot by smallholder farmers at less than $1 \%$ significance level. It indicates that the farmers who had landed near to the market and access to the market for the inputs and outputs of eucalyptus woodlot production were 2.035 times more likely to adopt eucalyptus woodlot than the local farmers who were far from the market and faced difficulty to ship their products to the market. The Woodlot producer farmers who have the farm land not far from the market can access the required materials easily for eucalyptus woodlot production and they could sell their products at right time efficiently, which affects the decision of local farmers to adopt eucalyptus woodlots on their land positively that help them to lives better lifestyle. The result related to (Nsiah, 2010) finding who pointed out the availability of a market near to the farm local farmers' decision to use the land to trees production increases.

Table 3.1: Logistic regression model output showing the Factors of local farmers' adoption of EWL

\begin{tabular}{lllll}
\hline Adoption of EWL & Coef. & St.Err. & t-value & p-value \\
\hline Ag & -.052 & .022 & -2.32 & $0.02^{*}$ \\
Sex & -.313 & .446 & -0.70 & 0.484 \\
Distance (km) & -2.035 & .052 & -2.81 & $0.005^{* *}$ \\
Family size & -0.35 & 1.319 & -0.55 & $0.000^{* *}$ \\
Educational & .889 & .515 & 1.73 & $0.084^{*}$ \\
status & & & & \\
LH size & .442 & .311 & 1.42 & 0.155 \\
Fertility of land & -1.945 & 0.65 & -0.54 & $0.001^{*}$ \\
Constant & 5.856 & 2.48 & 2.36 & $0.008^{* *}$ \\
& & & & \\
\hline
\end{tabular}

Number of obs

Prob > chi2

150.000

Pseudo r-squared

Chi-square
0.000

0.240

47.777 


\section{EPRA International Journal of Research and Development (IJRD)}

$* * * p<.01, * p<.1$

$* *$ = highly significant at 0.01 confidence level, ${ }^{*}=$ significant at 0.1 confident level, EEI = environmental and economic impact, EWL = Eucalyptus woodlot

\section{CONCLUSION AND RECOMMENDATION}

Local farmer's adoption of eucalyptus plantation in the form of woodlot goes to increasing. Furthermore, some farmers were using their fertile lands to tree production. The result indicated that landholding size, age of the farmers, and farmer's education level was positively and significantly affected the adoption of eucalyptus woodlot by local farmers. On the other hand, woodlot production adoption is negatively affected by family size and fertility of the land (based on farmer's perception) of the farmers. Therefore, the socioeconomic characteristics of the farmers were the main factors that can motivate or decline the adoption of eucalyptus woodlots by local farmers. Hence, to optimize the positive value of eucalyptus, and reduce its negative effects the concerned institution should give attention for changing the farmer's attitude, contribute to the enhancement of farmer's income. Government agencies need to work together with research institutions and the local community to set up and implement policies to support eucalyptus woodlot be managed sustainably and provide maximum economic, social, and environmental benefit for the local community in Ethiopia.

\section{REFERENCE}

1. Gessesse Dessie. (2011). Eucalyptus in East Africa: socio-economic and environmental issues. No.H043946. International Water Management Institute.

2. Gujarati. (2007). Essentials of econometrics.New Delhi, Mc-Graw-Hill.

3. Dereje Jenbere, Mulugeta Lemenih, and Habtemariam Kassa. ( 2012). Expansion of Eucalypt Farm Forestry and its Determinants in Arsi Negelle District, South Central Ethiopia. small scale forestry. Volume11, Issue 3 pp 389405.

4. Duguma L.A., Hager H. and Gruber M. ( 2009). The community-state forest interaction in Menagesha Suba area, Ethiopia: the challenges and possible solutions. Forests, Trees, and Livelihoods . .

5. Endalew, M. (2016). Economic Contribution of Participatory Forest Management Approach and its Major Implementation Challenges in the case of Bale Zone, Oromia Region, Ethiopia.

6. Harrison S., J. H. (2002). Socio-economic research methods in forestry: a training manual. Cairns: Cooperative Research Centre for Tropical Rainforest Ecology and Management.
7. Ho, A.K., Sidanius, J., Pratto, F., Levin, S., Thomsen, L., Kteily, N., \& Sheehy-Skeffington, J. (2012). Social dominance orientation: Revisiting the structure and function of a variable predicting social and political attitudes.Journal of Personality a Peand Social Psychology Bulletin, 583-606.

8. Kebede Gizachew. (2017). Expansion of Eucalypt Woodlot and Its Factors in Cheha District, Southern Ethiopia.

9. Matiku, P. (2012). The impact of participatory natural resources management on forest integrity and livelihood systems in Arabuko-Sokoke forest, Kenya, Ph.D. thesis Kenyatta University, Nairobi, Kenya.

10. Nsiah. (2010). Contribution of Farm Forest Plantation Management to the Livelihood Strategies of FarmHouseholds in the High Forest Zone of Ghana. A Dissertation submitted in partial fulfillment of the requirements for the degree of Doctor Rerum silvaticarum.

11. Shifa, M., Leibbrandt, M., Wittenberg, M. ( 2015). Does Tenure Insecurity Explain the Variations in LandRelated Investment Decisions in Rural Ethiopia? A Southern Africa Labor and Development ResearchUnit Working ., (p. 150). Cape Town: SALDRU, University.

12. Summers, P.M., Browder, J.O. \& Pedlowski, A.M.). T. (2004). Tropical Forest Management and SilviculturalPractices by Small Farmers in Brazilian Amazon. Recent farm-level evidence from Rodonia. Forest ecology and management. .

13. Yamane. (1967). Statistics. An Introductory Analysis, k: Harper and Row. 2nd Ed. New York.

14. Yetebitu Moges. (2010). Eucalypts trees and the environment: A new perspective in times of climate change.

15. Zerfu. (2002). Ecological impact evaluation of Eucalyptus plantation in comparison with agricultural and grazing land-use types in the highlands of Ethiopia. Ph. D. dissertation, Institute of Forest Ecology, Vienna University. 